\title{
Top-down control of phytoplankton by oysters in Chesapeake Bay, USA: Comment on Pomeroy et al. (2006)
}

\author{
Roger I. E. Newell ${ }^{1, *}$, W. Michael Kemp ${ }^{1}$, James D. Hagy III ${ }^{2}$, Carl F. Cerco ${ }^{3}$, \\ Jeremy M. Testa ${ }^{1}$, Walter R. Boynton ${ }^{4}$ \\ ${ }^{1}$ University of Maryland Center for Environmental Science, Horn Point Laboratory, PO Box 775, Cambridge, \\ Maryland 21613, USA \\ ${ }^{2}$ US Environmental Protection Agency, NHEERL, Gulf Ecology Division, Gulf Breeze, Florida 32561, USA \\ ${ }^{3}$ US Army Engineer Research and Development Center, Mail Stop EP-W, 3909 Halls Ferry Road, Vicksburg, \\ Mississippi 39180, USA \\ ${ }^{4}$ University of Maryland Center for Environmental Science, Chesapeake Biological Laboratory, PO Box 38, Solomons, \\ Maryland 20688, USA
}

\begin{abstract}
Pomeroy et al. (2006) proposed that temporal and spatial mismatches between eastern oyster filtration and phytoplankton abundance will preclude restored stocks of eastern oysters from reducing the severity of hypoxia in the deep channel of central Chesapeake Bay. We refute this contention by presenting arguments, data, and model results, overlooked by these authors. Our analysis indicates that oyster populations living on extensive reefs along the flanks of the mainstem Bay could substantially reduce summer phytoplankton growth and particulate organic carbon deposition to deep waters of the central channel. Because hypoxia in these deep waters is maintained through microbial decomposition of organic carbon generated by summer phytoplankton production, we conclude that reduced carbon fluxes to the deep channel associated with greatly increased oyster grazing could reduce the severity of hypoxia.
\end{abstract}

KEY WORDS: Algal blooms · Biodeposition · Crassostrea virginica · Chesapeake Bay · Hypoxia · Oyster $\cdot$ Restoration $\cdot$ Suspension-feeder $\cdot$ Water quality

\section{INTRODUCTION}

Pomeroy et al. (2006) present arguments aimed at refuting the hypothesis that the extirpation of once highly abundant eastern oysters Crassostrea virginica has removed their role as dominant grazers of phytoplankton in Chesapeake Bay, USA (Newell 1988). Newell's hypothesis implies that reduced consumption of phytoplankton by oysters has exacerbated the effects of anthropogenic nutrient enrichment on phytoplankton production, and of associated eutrophication effects during the last half-century (Kemp et al. 2005, Newell et al. 2005). The principal lines of reasoning advanced by Pomeroy et al. (2006) relate to purported temporal and spatial mismatches between potential oyster filtration and phytoplankton abundance. This argument suggests that, whereas oyster grazing is confined to the estuary's summer season and its shallow waters, phytoplankton abundance peaks in spring and in the Bay's deeper open waters. Although the focus of their argument is confined to the potential impact of oysters on summer hypoxia, it is important to note that 
recent studies have emphasized a much broader range of influences that oysters and other bivalves may exert on ecosystem processes in shallow estuaries (reviewed by Dame 1996, Coen et al. 2007, this volume). Losses of bivalve populations result in (1) degradation of habitat for diverse sessile and mobile animals (e.g. Coen et al. 1999), (2) increased turbidity that reduces abundance of seagrasses and benthic microalgae (e.g. Newell \& Koch 2004), and (3) reduced rates of denitrification and nutrient burial (e.g. Newell et al. 2005).

\section{SPRING AND SUMMER BLOOMS SUSTAIN HYPOXIA}

The central premise in the 'temporal mismatch' argument of Pomeroy et al. (2006) is their presumption that bottom-water hypoxia in the mesohaline part of the Bay during summer is both initiated and maintained by microbial respiration of particulate organic carbon (POC) deposited from the spring phytoplankton bloom. This reasoning fails to recognize that, although substantial ungrazed POC from the spring bloom does enter the sub-pycnocline waters of the central channel to fuel the spring decline in bottom-water $\mathrm{O}_{2}$, this organic matter input is insufficient to sustain the benthic and bottom-water respiration rates that maintain hypoxia throughout the summer (Kemp et al. 1992, 1999, Hagy 2002, Hagy et al. 2005). The observed summer sub-pycnocline respiration rates in this region require additional organic carbon inputs that are provided by high summer rates of net plankton community production in overlying surface waters and in adjacent littoral regions (Smith \& Kemp 1995, Kemp et al. 1997).

In contrast to the spring phytoplankton biomass peak, which is largely dependent on an accumulated nutrient pool associated with spring runoff, the summer production maximum is sustained by rapid nutrient recycling, with each atom of $\mathrm{N}$ delivered in spring being potentially recycled 7 times throughout the summer (Malone et al. 1988). Sediment trap studies of the composition and quantity of sinking POC in the mesohaline mid-Bay indicate that particles are composed of mainly intact diatom cells during spring, while a second deposition peak in July consists primarily of zooplankton fecal pellets, diatom chains, and other algal detritus (Kemp \& Boynton 1992, Kemp et al. 1999). Rates of POC sinking integrated over the summer are generally similar to or slightly lower than those occurring in spring. This conclusion is further supported by analysis of spring pools of chlorophyll a on the sediment surface throughout the Bay (Hagy et al. 2005). This point is key to the question of potential oyster impact on hypoxia, because it means that inputs of carbon that would support sub-pycnocline $\mathrm{O}_{2}$ depletion can be regulated through phytoplankton grazing by oysters and other herbivores, whether that grazing occurs in spring or summer.

Like most temperate aquatic animals, the eastern oyster's physiological processes, including water filtration, are highly dependent on ambient water temperatures, with summer rates being substantially higher than those throughout the rest of the year (e.g. Newell \& Langdon 1996). Although we acknowledge this general point, which is an important aspect of the argument in Pomeroy et al. (2006), the filtration rate that they used for calculating potential oyster impact on the spring algal bloom should probably be increased 3-fold. Pomeroy et al. (2006) used a value for oyster clearance rate $\left(0.45 \mathrm{l} \mathrm{h}^{-1} \mathrm{~g}^{-1}\right)$ appropriate for March temperatures, noting that this is when the spring diatom bloom is initiated (Hagy et al. 2005). The spring bloom in the mesohaline Bay generally runs from early March through May, with a peak in April (Harding et al. 2002). Therefore, it would be more appropriate to use a time-varying rate running between $\sim 0.5$ and 2.01 $\mathrm{h}^{-1} \mathrm{~g}^{-1}$ (based on mean temperatures and on the relationship given in Newell et al. 2005) to estimate oyster grazing effects on the spring bloom. The important point is that the inherently low grazing rates on algal cells by oysters as well as other benthic and pelagic herbivores allow the spring phytoplankton biomass to accumulate - this is the nature of the spring bloom in coastal systems such as Chesapeake Bay (Malone 1992, Harding et al. 1999, 2002, Kemp et al. 1999); the statement that 'low springtime filtration rates would make it impossible for oysters to control the spring bloom' (Pomeroy et al. 2006, p. 301) is a truism that pertains to all phytoplankton grazers. As indicated above, the most relevant point that counters their argument is the fact that grazing in warmer months by more abundant oysters (as well as by other benthic herbivores) can significantly retard the supply of carbon to the sub-pycnocline, the process that is necessary to maintain summer hypoxia.

\section{OYSTERS ACCESS PHYTOPLANKTON IN SHALLOWER WATER}

The central premise of the Pomeroy et al. (2006) 'spatial mismatch' argument is that oysters are confined to the relatively shallow waters that flank the mainstem Bay and dominate its tributary estuaries, while most of the phytoplankton production occurs in waters overlying the deep central mainstem channel. Whereas the first part of this argument is generally true, the second is certainly false. It is important to recognize that more than half of the Bay has mean water depths that are 
shallower than the depth of the upper mixed layer ( 6 to $10 \mathrm{~m}$ ), which generally coincides with the euphotic depth (e.g. Wofsy 1983, Kemp et al. 1997). This implies that at least half of the vertically well-mixed waters of the Bay are in direct contact with the benthos and with the fauna that occupies these habitats. Furthermore, the charts presented by Pomeroy et al. (2006) to depict historical distribution of oyster bars and their relationship to the current distribution of spring phytoplankton (their Fig. 1) are misleading. Some oyster bars have been omitted, and the 3-dimensional orientation of oyster reefs (Lund 1957, Hargis \& Haven 1999, Kennedy \& Sanford 1999) has been ignored. Unharvested oyster reefs form structures with a complex vertical relief (Powell et al. 1987, DeAlteris 1988, 1989, Hargis 1999, Hargis \& Haven 1999, Smith et al. 2003), which interacts with tidal currents to generate turbulent mixing that enhances particle transfer across the benthic boundary layer (e.g. Wildish \& Kristmanson 1997, p. 341).

Pomeroy et al. (2006) illustrated their contention that phytoplankton blooms are spatially separated from eastern oyster habitat along the flanks of Chesapeake Bay. They stated that their illustration (their Fig. 1; re- produced here in Fig. 1, right panel) is based on an unpublished report by Hood \& Boicourt (2005), which should have been cited as Li et al. (2005). Li et al. (2005) developed a biophysical model that they used to predict the location of nitrogen in phytoplankton blooms. The model predicts for a spring period in 1996 that high phytoplankton nitrogen of $\sim 15$ to $20 \mathrm{mmol} \mathrm{N}$ $\mathrm{m}^{-3}$ would be broadly distributed across the width of the Bay, reaching both the eastern and western shores along most of the mesohaline portion (Fig. 1). Moreover, extensive aerial surveys of chlorophyll a concentrations taken at 1 to $4 \mathrm{wk}$ intervals from 1989 to 2006 (available at: www.cbrsp.org), summarized by Miller \& Harding (2007), reveal that phytoplankton blooms in spring and summer tend to be either broadly distributed across the entire Bay or concentrated in the flanks. The diagram created by Pomeroy et al. (2006) does not accurately represent the modeled or field measurements of the spatial distribution of phytoplankton, and instead shows high concentrations of phytoplankton constrained to waters above the deep channel (Fig. 1). Pomeroy et al. (2006) then utilize this to support their argument that there is a high degree of spatial separation between oysters and phytoplankton

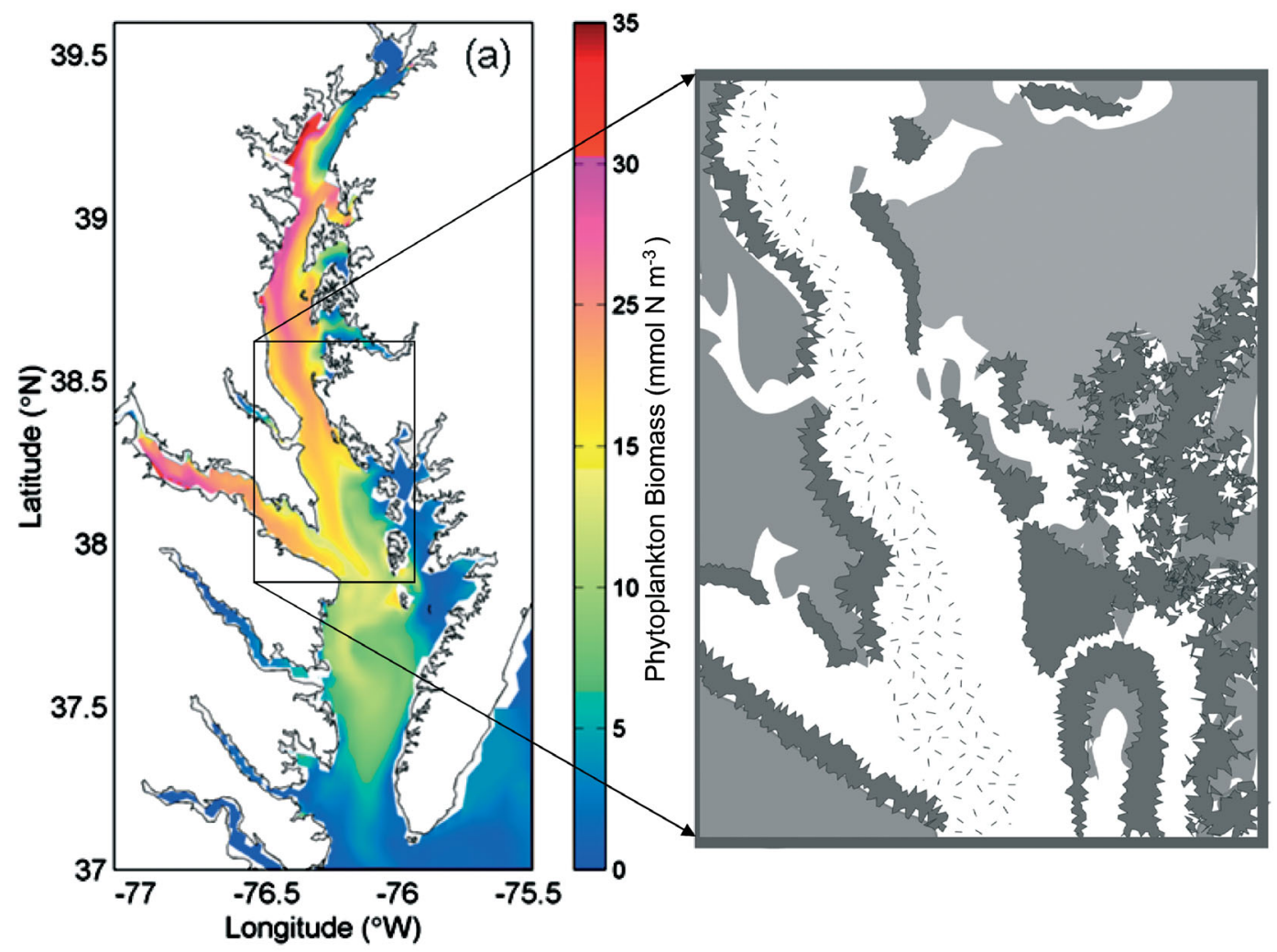

Fig. 1. Left: Output from a biophysical model for Chesapeake Bay that shows the spatial distribution of phytoplankton biomass (modeled as mmol $\mathrm{m}^{-3}$ ) during spring 1996 (from Li et al. 2005, their Fig. 18). Right: Fig. 1 from Pomeroy et al. (2006) purported to show 'the active core of a major spring diatom bloom (stippled) in central Chesapeake Bay.' Although Pomeroy et al. (2006) state that this figure is based on the phytoplankton $\mathrm{N}$ concentrations shown in the left panel, their diagram does not accurately reproduce the broad distribution of phytoplankton biomass across the width of the Bay 
blooms. Based on the aerial surveys of chlorophyll a concentrations, we conclude that oyster reefs in the Bay, although generally confined to waters $<8$ m deep, historically had effective access to a substantial proportion of the estuary's phytoplankton communities and that the complex vertical relief of these reef structures tended to minimize re-filtration, enhancing oyster feeding efficiency. Oysters living in such locations would consume phytoplankton, and undigested organic material in their feces and pseudofeces would be incorporated into the surrounding sediments (Haven \& Morales-Alamo 1966, 1968, Newell et al. 2005). In such aerobic locations the remaining organic material is subject to metazoan and bacterial decomposition that does not contribute to the development of hypoxia in the bottom waters of the central channel of the Bay.

\section{LIMITS TO TOP-DOWN CONTROL BY EXTANT BENTHIC SUSPENSION-FEEDERS}

Pomeroy et al. (2006) also suggest that the filtration capacity of existing benthic suspension feeding guilds (Thompson \& Schaffner 2001, Schaffner \& Thompson 2002) is similar to that estimated for historical oyster stocks. Based on this supposition, Pomeroy et al. argue that the inability of these extant benthic grazer communities to regulate phytoplankton and bottom water hypoxia implies that oyster grazing was never important in controlling summer sub-pycnocline hypoxia in the mesohaline part of the Bay. This line of reasoning ignores the fact that benthic filter-feeding invertebrates are not evenly distributed along the Bay's main salinity gradient. Presently, the polyhaline (lower Bay) benthic community contains a diverse guild of suspension-feeders (e.g. Diaz \& Schaffner 1990, Thompson \& Schaffner 2001), while the upper oligohaline region of the estuary is dominated by dense beds of bivalves (e.g. Gerritsen et al. 1994).

Benthic filtration in both of these regions appears capable of regulating phytoplankton abundance and growth (Gerritsen et al. 1994, Thompson \& Schaffner 2001), but in the mesohaline region, where summer hypoxia prevails, benthic filter feeders are currently too sparse to exert significant grazing pressure on phytoplankton (Gerritsen et al. 1994). The eastern oyster is one of the most euryhaline of all indigenous bivalves, growing well at salinities ranging from 5 to 34 (Shumway 1996). Following the extirpation of oysters from the mesohaline Bay during the last century, no other benthic suspension feeding species has succeeded in occupying this niche (Diaz \& Schaffner 1990, Newell \& Ott 1999). The historically extensive oyster populations in this part of the mesohaline Bay were likely supported by high phytoplankton produc- tion typical of the chlorophyll maximum zone located just seaward of the estuarine turbidity maximum; the location of this zone varies seasonally and at short time scales, but it is almost always found between latitudes $39^{\circ} 10^{\prime} \mathrm{N}$ and $39^{\circ} 28^{\prime} \mathrm{N}$, i.e. in the vicinity of Kent Island, MD (Sanford et al. 2001). Consequently, there is now a regional mismatch between the high biomass of suspension feeders in the oligohaline and polyhaline regions, and the Bay's mesohaline region, where summer phytoplankton growth is high (Harding et al. 2002, Miller \& Harding 2007) and bottom water oxygen concentrations are low (Kemp et al. 2005).

\section{SIMULATION MODELS OF THE ECOLOGICAL FUNCTION OF OYSTERS}

The preceding discussion illustrates that the question of oyster top-down control of phytoplankton growth in the Bay depends on the correspondence between spatial distributions and temporal sequences of phytoplankton and oysters. The coarse scales of the original illustrative calculations developed by Newell (1988), which were adopted by Pomeroy et al. (2006), are not adequate to address these oyster-phytoplankton interactions. Recently, Cerco \& Noel $(2005,2007)$ extended a coupled biophysical model of the Bay's ecosystem dynamics (Cerco \& Cole 1993) to simulate eastern oyster filtration and associated complex ecosystem changes at fine temporal $(\mathrm{h})$ and spatial (1 m vertical $\times 1 \mathrm{~km}$ horizontal) resolution. They estimated that ecological responses to 10 - and 100-fold increases (from present low levels) in oyster abundance would increase summer mean $\mathrm{O}_{2}$ concentrations beneath the mesohaline Bay pycnocline by $\sim 20$ and $~ 80 \%$, respectively, over today's baseline levels $\left(1.35 \mathrm{mg} \mathrm{l}^{-1}\right)$. Moreover, these modeling scenarios predicted that the area of Bay-bottom where water clarity is sufficient to allow seagrass growth would increase by 20 and $60 \%$, respectively. On a Bay-wide basis, projected bottomwater $\mathrm{O}_{2}$ improvements from a 100-fold increase in oyster abundance are comparable to improvements associated with mandated reductions in anthropogenic nutrient loading to the Bay (26 vs. $30 \%$ respectively), while projected improvements in seagrass biomass exceed those associated with nutrient reductions (60 vs. $38 \%$ ). Model simulations also indicated that oyster restoration in the shallow and enclosed Bay tributaries will tend to have the greatest impact on improvements in water clarity and seagrass habitat.

The value of strategically siting oyster restoration activities has also been confirmed by other modeling studies. For example, Fulford et al. (2007) developed a spatially-explicit algorithm to estimate oyster removal 
of phytoplankton biomass from 36 Bay regions, with oyster feeding rates adjusted for observed seasonal variations in water temperature, $\mathrm{O}_{2}$, suspended solids and phytoplankton biomass ( 3 size classes). Model scenarios indicated that, despite the current negligible impact of oysters on Bay phytoplankton, a 25-fold increase in oyster abundance over present day low levels would remove algal cells in Bay tributaries at annual mean rates that equal or exceed observed specific growth rates for phytoplankton.

\section{CONCLUSIONS}

We conclude that, in contradiction to the assertions in Pomeroy et al. (2006), most of the available information supports the hypothesis of Newell (1988) that eastern oysters once provided an important check on phytoplankton production. This suggests that the demise of the oyster has exacerbated the current effects of eutrophication in the Bay. This conclusion leads us to the recommendation that oyster restoration should be an important component of a multi-faceted program to reduce the adverse affects of human development on Chesapeake Bay. The use of oyster restoration in addition to nutrient control is an important element of the overall strategy because it is one of the few possibilities to control ecosystem processes after anthropogenic nutrient inputs have altered the Bay (Newell et al. 2005). Forecasts of how the Bay might respond to increases in oyster abundance must be viewed with caution, however, because the ecosystem may well develop an alternative trophic state, rather than return directly to the original condition (e.g. Dame 2005). Although management plans call for a Bay-wide 10-fold increase in oysters over the low abundances present in 1994 (Chesapeake 2000 Agreement; www.chesapeakebay.net/c2k.htm), ongoing disease epizootics (Ford \& Tripp 1996) and relentless harvest pressure continue to promote a general decline of eastern oyster populations throughout the Bay (e.g. Jordan \& Coakley 2004). In tributaries of the upper Bay, where oyster diseases are less virulent, there has been modest success in restoring nascent oyster reefs in recent years. By focusing on restoration in small regions, some of the environmental benefits discussed above may begin to be achieved, even if Bay-wide restoration of historic oysters stocks is not immediately achievable. Recognition of the diverse ecosystem benefits provided by oyster populations (see also Coen et al. 2007), is a necessary precursor and stimulus for actions to conserve and rebuild eastern oyster populations, so that they can once again provide beneficial ecosystem services and ultimately, perhaps, support a sustainable fishery.
Acknowledgements. We are grateful to Ming Li for granting permission to reproduce an unpublished diagram from Li et al. (2005). Loren Coen participated in initial discussions.

\section{LITERATURE CITED}

Cerco CF, Cole T (1993) Three-dimensional eutrophication model of Chesapeake Bay. J Environ Eng 119:1006-1025

Cerco CF, Noel MR (2005) Evaluating ecosystem effects of oyster restoration in Chesapeake Bay. Report of U.S. Army Engineer Research and Development Center, Vicksburg MS (www.chesapeakebay.net/pubs/Cerco_Noel_final.pdf)

Cerco CF, Noel MR (2007) Can oyster restoration reverse cultural eutrophication in Chesapeake Bay? Estuar Coast 30:1-13

Coen LD, Luckenbach MW, Breitburg DL (1999) The role of oyster reefs as essential fish habitat: a review of current knowledge and some new perspectives. In: Benaka LR (ed) Fish habitat: essential fish habitat and rehabilitation. American Fisheries Society, Symposium 22, Bethesda, MD, p 438-454

Coen LD, Brumbaugh RD, Bushek D, Grizzle R, Luckenbach MW, Posey MH, Powers SP, Tolley SG (2007) Ecosystem services related to oyster restoration. Mar Ecol Prog Ser 341:303-307

Dame RF (1996) Ecology of marine bivalves: an ecosystem approach. CRC Marine Science Series, Boca Raton, FL

Dame RF (2005) Oyster reefs as complex ecological systems. In: Dame RF, Olenin S (eds) The comparative roles of suspension feeders in ecosystems. NATO ASI Sci Ser 4 Earth Environ Sci, Springer-Verlag, Berlin, p 331-343

DeAlteris JT (1988) The geomorphic development of Wreck Shoal, a subtidal oyster reef of the James River, Virginia. Estuaries11:240-249

DeAlteris JT (1989) The role of bottom current and estuarine geomorphology on the sedimentation processes and productivity of Wreck Shoal, an oyster reef of the James River, Virginia. In: Neilson BJ, Kuo A, Brubaker J (eds) Estuarine circulation. Humana Press, Clifton, NJ, p 279-307

Diaz RJ, Schaffner LC (1990) The functional role of estuarine benthos. In: Haire M, Krome EC (eds) Perspectives on the Chesapeake Bay: advances in estuarine sciences. Publication CBP/TRS/90, Chesapeake Research Consortium, Gloucester, VA, p 25-56

Ford SE, Tripp MR (1996) Diseases and defense mechanisms. In: Kennedy VS, Newell RIE, Eble A (eds) The eastern oyster, Crassostrea virginica. Maryland Sea Grant Publication, College Park, MD, p 581-660

Fulford RS, Breitburg DL, Newell RIE, Kemp WM, Luckenbach M (2007) Effects of oyster population restoration strategies on phytoplankton biomass in Chesapeake Bay: a flexible modeling approach. Mar Ecol Prog Ser 336:43-61

Gerritsen J, Holland AF, Irvine DE (1994) Suspension-feeding bivalves and the fate of primary production: an estuarine model applied to Chesapeake Bay. Estuaries 17:403-416

Hagy JD (2002) Eutrophication, hypoxia and trophic transfer efficiency in Chesapeake Bay. PhD dissertation, University of Maryland, College Park, MD

Hagy JD III, Boynton WR, Jasinski DA (2005) Modelling phytoplankton deposition to Chesapeake Bay sediments during winter-spring: interannual variability in relation to river flow. Estuar Coast Shelf Sci 62:25-40

Harding LW, Degobbis D, Precali R (1999) Production and fate of phytoplankton: annual cycles and interannual variability. In: Malone T, Malej A, Harding L, Smodlaka N, Turner $\mathrm{R}$ (eds) Ecosystems at the land-sea margin: drainage 
basin to coastal sea. American Geophysical Union, Estuar Coast Sci Ser no. 55, p 131-172

Harding LW Jr, Mallonee ME, Perry ES (2002) Toward a predictive understanding of primary productivity in a temperate, partially stratified estuary. Estuar Coast Shelf Sci 55:437-463

HargisWJ (1999) The evolution of the Chesapeake oyster reef system during the Holocene epoch. In: Luckenbach MW, Mann R, Wesson JA (eds) Oyster reef habitat restoration: a synopsis and synthesis of approaches. Virginia Institute of Marine Science Press, Gloucester Point, VA, p 5-23

Hargis WJ, Haven DS (1999) Chesapeake oyster reefs, their importance, destruction and guidelines for restoring them. In: Luckenbach MW, Mann R, Wesson JA (eds) Oyster reef habitat restoration: a synopsis and synthesis of approaches. Virginia Institute of Marine Science Press, Gloucester Point, VA, p 329-358

Haven DS, Morales-Alamo R (1966) Aspects of biodeposition by oysters and other invertebrate filter feeders. Limnol Oceanogr 11:487-498

Haven DS, Morales-Alamo R (1968) Occurrence and transport of fecal pellets in suspension in a tidal estuary. Sediment Geol 2:141-151

Jordan SJ, Coakley JM (2004) Long-term projections of eastern oyster populations under various management scenarios. J Shellfish Res 23:63-72

Kemp WM, Boynton WR (1992) Benthic-pelagic interactions: nutrient and oxygen dynamics. In: Smith DE, Leffler $M$, Mackiernan G (eds) Oxygen dynamics in the Chesapeake Bay. A synthesis of research. University of Maryland Sea Grant, College Park, MD, p 149-221

Kemp WM, Sampou PA, Garber J, Tuttle J, Boynton WR (1992) Seasonal depletion of oxygen from bottom waters of Chesapeake Bay: relative roles of benthic and planktonic respiration and physical exchange processes. Mar Ecol Prog Ser 85:137-152

Kemp WM, Smith EM, Marvin-DiPasquale M, Boynton WR (1997) Organic carbon balance and net ecosystem metabolism in Chesapeake Bay. Mar Ecol Prog Ser 150:229-248

Kemp WM, Puskaric S, Faganeli A, Smith E, Boynton W (1999) Pelagic-benthic coupling and nutrient cycling. In: Malone T, Malej A, Harding L, Smodlaka N, Turner R (eds) Ecosystems at the land-sea margin: drainage basin to coastal sea. American Geophysical Union, Estuar Coast Sci Ser no. 55, p 295-339

Kemp WM, Boynton,WR, Adolf JE, Boesch DF and 14 others (2005) Eutrophication of Chesapeake Bay: historical trends and ecological interactions. Mar Ecol Prog Ser 303:1-29

Kennedy VS, Sanford LP (1999). Characteristics of relatively unexploited beds of the eastern oyster, Crassostrea virginica, and early restoration programs. In: Luckenbach MW, Mann R, Wesson JA (eds) Oyster reef habitat restoration: a synopsis and synthesis of approaches. Virginia Institute of Marine Science Press, Gloucester Point, VA, p 25-46

Li M, Hood RR, Boicourt WC (2005) A community model for Chesapeake Bay. NOAA and University of New Hampshire, CICEET Final Report (available at: http://rfp.ciceet. unh.edu/projects/search.php)

Lund EJ (1957) Self silting by the oyster and its significance for sedimentation geology. Publ Inst Mar Sci Univ Texas $4: 320-327$

Malone TC (1992) Effects of water column processes on dissolved oxygen, nutrients, phytoplankton and zooplankton. In: Smith DE, Leffler M, Mackiernan G (eds) Oxygen dynamics in the Chesapeake Bay. A synthesis of research. University of Maryland Sea Grant, College Park, MD, p 61-112

Editorial responsibility: Howard Browman (Associate Editorin-Chief), Storebø, Norway
Malone TC, Crocker LH, Pike SE, Wendler BW (1988) Influences of river flow on the dynamics of phytoplankton production in a partially stratified estuary. Mar Ecol Prog Ser 48:235-249

Miller WD, Harding LW Jr (2007) Climate forcing of the spring bloom in Chesapeake Bay. Mar Ecol Prog Ser 331:11-22

Newell RIE (1988) Ecological changes in Chesapeake Bay: are they the result of overharvesting the eastern oyster (Crassostrea virginica)? In: Lynch MP, Krome EC (eds) Understanding the estuary. Advances in Chesapeake Bay research, Chesapeake Research Consortium Publ 129, Gloucester Point, VA, p 536-546 (available at www.vims. edu/GreyLit/crc129.pdf)

Newell RIE, Koch EW (2004) Modeling seagrass density and distribution in response to changes in turbidity stemming from bivalve filtration and seagrass sediment stabilization. Estuaries 27:793-806

Newell RIE, Langdon CJ (1996) Mechanisms and physiology of larval and adult feeding. In: Kennedy VS, Newell RIE, Eble A (eds) The eastern oyster, Crassostrea virginica. Maryland Sea Grant Publication, College Park, MD, USA, p 185-230

Newell RIE, Ott J (1999) Macrobenthic communities and eutrophication. In: Malone T, Malej A, Harding L, Smodlaka N, Turner R (eds) Ecosystems at the land-sea margin: drainage basin to coastal sea. American Geophysical Union, Estuar Coast Sci Ser no. 55, p 265-293

Newell RIE, Fisher TR, Holyoke RR, Cornwell JC (2005) Influence of eastern oysters on nitrogen and phosphorus regeneration in Chesapeake Bay, USA. In: Dame RF, Olenin S (eds) The comparative roles of suspension feeders in ecosystems, NATO ASI Sci Ser 4 Earth Environ Sci, Springer-Verlag, Berlin, p 93-120

Pomeroy LR, D'Elia CF, Schaffner LC (2006) Limits to topdown control of phytoplankton by oysters in Chesapeake Bay. Mar Ecol Prog Ser 325:301-309

Powell EN, White ME, Wilson EA, Ray SM (1987) Small-scale spatial distribution of oysters (Crassostrea virginica) on oyster reefs. Bull Mar Sci 41:835-855

Sanford LP, Suttles SE, Halka JP (2001) Reconsidering the physics of the Chesapeake Bay estuarine turbidity maximum. Estuaries 24:655-669

Schaffner LC, Thompson ML (2002) Clearing the muddy waters: suspension feeders flourish in Chesapeake Bay. Estuarine Research Federation, meeting abstracts (available at http://www.erf.org/erf2001/abstracts/participants 16.html\#S)

Shumway SE (1996) Natural environmental factors. In: Kennedy VS, Newell RIE, Eble A (eds) The eastern oyster, Crassostrea virginica. Maryland Sea Grant Publication, College Park, MD, USA, p 467-513

Smith EM, Kemp WM (1995) Seasonal and regional variations in plankton community production and respiration for Chesapeake Bay. Mar Ecol Prog Ser 116:217-231

Smith GF, Bruce DG, Roach EB (2003) The location, composition and origin of oyster bars in mesohaline Chesapeake Bay. Estuar Coast Shelf Sci 56:391-409

Thompson ML, Schaffner LC (2001) Population biology and secondary production of the suspension feeding polychaete Chaetopterus veriopedatus: implications for benthic-pelagic coupling in lower Chesapeake Bay. Limnol Oceanogr 46:1899-1907

Wildish DJ, Kristmanson DD (1997) Benthic suspension feeders and flow. Cambridge University Press, Cambridge

Wofsy SC (1983) A simple model to predict extinction coefficients and phytoplankton biomass in eutrophic waters. Limnol Oceanogr 28:1144-1155 